\title{
Strength and Workability Improvement Potential of Admixture of Corn Cob Ash and Cement for Stabilizing Lateritic Soil
}

\author{
${ }^{1}$ Osuolale, O. M., ${ }^{* 2}$ Oluremi, J. R. and ${ }^{3}$ ADEDOKUN, S. I. \\ Department of Civil Engineering, Faculty of Engineering and Technology, \\ Ladoke Akintola University of Technology, PMB 4000, Ogbomoso. Nigeria. \\ E-mail: ${ }^{1}$ omosuolale@lautech.edu.ng; ${ }^{2}$ jroluremi@lautech.edu.ng; ${ }^{3}$ siadedokun lautech.edu.ng \\ *Corresponding Author: jroluremi@lautech.edu.ng
}

\begin{abstract}
A natural lateritic soil classified as A-7-5 (10) and CL based on AASHTO and USCS classification systems, was stabilized with up to $5 \%$ cement admixed with up to $12 \%$ CCA to assess their effect on its basic geotechnical properties such as particle size distribution, Atterberg limits, compaction, unconfined compressive strength and California bearing ratio. The liquid limit decreased and plastic limit increased while there is a reduction in corresponding plasticity index of the clay soil. There was an increase in Maximum Dry Density (MDD) and Optimum Moisture Content (OMC) of the stabilized soil sample, which increased with the increasing content of CCA and cement. Both the Unconfined Compressive Strength (UCS) and California Bearing Ratio (CBR) of the soil increased with increasing percentage of cement and CCA. Based on the results of this study, corn cob ash (CCA) cannot be used as a stand-alone stabilizer for this lateritic soil but with a more potent stabilizer for clay soil such as lime. It is therefore recommended that the mixture of $12 \% \mathrm{CCA}$ and $2.5 \%$ cement could be used to stabilize A-7-5 (10) lateritic soil for use as subbase material and $12 \%$ CCA and $5.0 \%$ cement could be used to stabilize A7-5 (10) lateritic soil for use as base material for improving pavement structure in terms of strength, stability and workability.
\end{abstract}

Keywords: Lateritic soil, Corn cob ash, Cement, Stabilization, Strength and Workability

DOI: $10.7176 /$ JIEA/9-7-06

Publication date: December $31^{\text {st }} 2019$

\section{Introduction}

There are several highway pavement failures in Nigeria and these failures had been attributed to inadequate strength of the foundation materials, properties of construction materials, subgrade conditions, environmental conditions, traffic loading, lack of drainage and poor workmanship (Osuolale, et al., 2012). The commonest material for the construction of the subgrade and subbase in the tropics is lateritic soil. Laterite soil is a common construction material available in almost all the countries of the humid tropics of the world (Akinrinlola 1991). This available soil does not have adequate engineering properties to really carry the expected wheel load, especially high traffic density. Therefore, the need for improvement of the engineering properties of laterite soil has been a paramount concern to the highway engineers especially in Nigeria where the cost of locating, burrowing and hauling of alternative suitable soil may be too expensive. Soil improvement is achieved through either the stabilization or modification of the unsuitable or unstable soil.

Soil stabilization, normally considered an economical solution in places where granular materials are not available, is any treatment (including, technically, compaction) applied to a soil to improve its strength, reduce its vulnerability to water and withstand the stresses imposed on it by traffic under all weather conditions without deformation (O'Flaherty, 2002); while modification is the treatment of the soil to achieve improvement in the consistency properties of the soil. The conventional materials that are commonly used as stabilizers in improving engineering properties of soil are lime, cement, and emulsified asphalt. The choice and effectiveness of a stabilizer depend on the type of soil and its field conditions; in addition, knowledge of mechanical behaviour of treated soil is equally important in selecting the stabilizer (Muhunthan and Sariosseiri; 2008).

Portland cement is the most important hydraulic cement utilized extensively in various types of cement stabilization of lateritic soils. Cement acts as a binder and provides the much-desired hardening and strengthening properties. The addition of cement also increases compressive strength, the resistance of lateritic soils to freezing and thawing, wetting and drying. It also affects the particle size distribution of the soils by increasing the size of fine particles. Conventionally, Portland cement has been used to appreciably improve the properties of soils (Ola, 1975; 1983; Osula, 1989; Scullion and Harris, 1998; Berthelot et al., 2005; Gadzama, 2009). Udoeyo, (2002) also stated that cement stabilized samples exhibited the highest cured strength when compared with lime and some mixture of both. Gadzama (2009) also established that $4 \%$ of cement can be recommended as optimal content to stabilize soil from parts of Northern Nigerian. However, the cost of production of conventional stabilizers coupled with the environmental pollution associated with its production and usage has led to continuous researches on the need for alternatives material as a stand-alone material for stabilization. The alternatives which include fly ash, 
geofiber, and polymer stabilizers. saw-dust ash, rice husk ash, lime and cement kiln dust (Osinubi and Medubi, 1997; Osinubi, 2000; 2006; Brooks, 2009; Osinubi, et al., 2009; 2011; Oluremi et al., 2012; 2016a; 2016b; 2017; Osinubi et al.,2017). Application of recycled and waste products has improved chemical and mechanical stabilization techniques. Such waste materials as crushed old asphalt pavement, copper and zinc slag, paper mill sludge, and rubber tire chips (Osipov and Filimonov, 2002).

Some agricultural waste products that have been blended with cement because of their pozzolanic properties include rice husk ash (Nehdi et al., 2003), sawdust ash (Udoeyo, 2002) and corncob ash (Adesanya and Raheem, 2009), locust bean waste ash (Osinubi et al., 2011). Corncob is a by-product of corn production, with about 160$180 \mathrm{~kg}$ corncobs generated for every 1 ton of corn produced (Zhang et al., 2013). However, most of the corncobs generated worldwide are still discarded as waste (Zhang et al., 2010). This waste can be converted to ash which could be used in stabilizing unstable soil, thereby ameliorating its environmental pollution impact as waste. A further advantage to the environment is that partial or total replacement of cement in soil stabilization with a biomass waste will reduce the overall greenhouse gas emission from the construction industry because emissions from CCA production is carbon neutral (Chungsangunsit et al., 2007). Akinwumi et al., (2015) stated that the sum of $\mathrm{SiO}_{2}, \mathrm{Al}_{2} \mathrm{O}_{3}$ and $\mathrm{Fe}_{2} \mathrm{O}_{3}$ for corncob ash is $74.38 \%$, which is greater than the minimum $70 \%$ recommended by ASTM C618 (2003) for use as Class F pozzolanic material in concrete. The cement and corncob ash are essentially rich in $\mathrm{CaO}$ and $\mathrm{SiO}_{2}$, as shown in Figure 1.

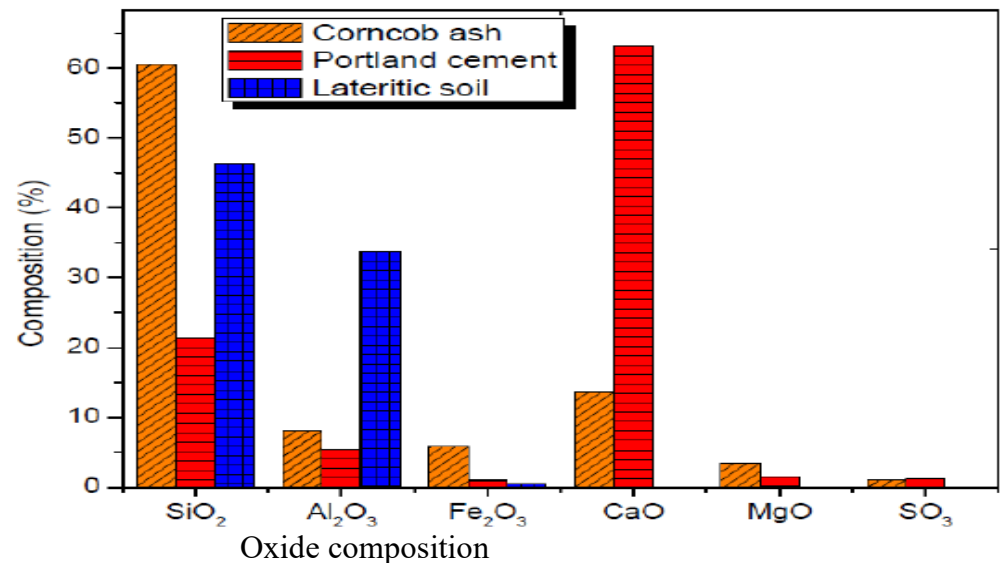

Figure 1: Chemical Composition of Materials Used (Akinwumi et al, 2015)

Although research works on corncob ash blended with Portland cement to produce concrete have been carried out, few researchers have investigated the effects of corncob ash on the index properties and strength properties of lateritic soil. (Osinubi, 1998; Osinubi and Nwaiwu, 2006) worked on the effect of corncob ash on some properties of lime stabilized soil. Particularly, Jimoh and Apampa (2014) applied up to 7.5\% corn cob ash to lateritic soil, the plasticity index and OMC of the stabilized soil increased with an increasing percentage of CCA, while the maximum dry density of the soil, reduced. However, $3 \%$ of CCA could be optimally used to improve the strength characteristics of the stabilized soil. In another research, investigation on the effect of blending CCA and cement, in ratios 1:2, 1:1 and 2:1, on the UCS of the soil was reported by Jimoh and Apampa (2014); the UCS increased with increasing content of cement with 1:2 blend of CCA to cement gave higher UCS. However, their work failed to report on the effects of the blends of corncob ash and cement on the Atterberg limits, compaction characteristics, unsoaked and soaked CBR, swell potential and permeability of the lateritic soil.

This study, therefore, investigated the influence of corncob ash-cement on the properties of laterite soil in relation to its consistency indices, moisture content-dry density and strength characteristics of corncob ash-cement stabilized laterite

\section{Materials and Methods}

Lateritic soil, dried Corn Cobs and cement were used basically for this study. Geotechnical methods of soil testing were used to assess the suitability of the cement stabilized lateritic soil admixed with corn cob ash in relation to its strength and durability.

\subsection{Materials Collection and Preparation}

Lateritic Soil

Laterite soil used for this study was obtained as a disturbed sample from a burrow pit along Ogbomoso-Ilorin 
Express road, Ogbomoso, Nigeria. The sample was taken to the geotechnical Laboratory of Department of Civil Engineering, LAUTECH, Ogbomoso where it was air-dried and stored.

\section{Corn Cob Ash}

Dried corn cob, a by-product of maize were collected in large quantity from maize processing market at Odo-Oba village, Ogbomoso, Oyo State. The corncobs were further air-dried, placed on a flat iron sheet and burnt to ash. The ash was collected and sieved through sieve No 200 (75 $\mu \mathrm{m}$ aperture) to obtain fine material similar to cement. The fine ash was collected and stored in polythene bags to prevent pre-hydration from the atmosphere.

Cement

Ordinary Portland cement of Grade 42.5R was procured from cement stores in Ogbomoso, Oyo State, Nigeria for this study.

\subsection{Materials characterization}

Materials used were characterized by determining the elemental composition of the corn cob ash used as admixture in the stabilization. X-Ray Fluorescence (XRF) Analyzer was used to obtain both the elemental and oxide composition of the ash as shown in Figure 1.

\subsection{Geotechnical Characterization}

Lateritic soil sample was stabilized with up to $5 \%$ cement in step concentration of $2.5 \%$ and admixed with up to $12 \%$ CCA in step concentration of 3\%, as shown in Table 2 and the following standard geotechnical tests were performed on both the natural soil and the stabilized soil samples in accordance to BS 1377 (1990) and BS 1924 (1990).

\begin{tabular}{lllllll}
\multicolumn{5}{c}{ Table 1: Proportion of CCA and C mix by percentage weight of soil sample } \\
\cline { 1 - 4 } & 0 & 3 & 6 & 9 & 12 \\
0 & 0,0 & 0,3 & 0,6 & 0,9 & 0,12 \\
2.5 & $2.5,0$ & $2.5,3$ & $2.5,6$ & $2.5,9$ & $2.5,12$ \\
5 & 5,0 & 5,3 & 5,6 & 5,9 & 5,12 \\
\hline
\end{tabular}

\section{A. Sieve analysis}

500 grams of the dried soil sample was soaked for 24 hours before washing on BS sieve No 200 ( $75 \mu$ m aperture) to completely remove the clay materials. The sample was oven-dried for 24 hours at a temperature of $110^{\circ} \mathrm{C}$. Thereafter, it was removed from the oven, cooled and sieved through a set of sieve using mechanical sieve shaker. Soil sample retained on each was collected and measured and the percentage retained and passing each sieve was determined from the recorded values. The percentage passing each sieve was plotted against the sieve size. This procedure was repeated for each of the treated lateritic soil.

\section{B. Atterberg limits}

Atterberg limits are the basic measures of the nature of fine-grained soils in changing from solid to semi-solid, then to plastics and thereafter liquid state. Atterberg limits consist of liquid and plastic limits

\section{Liquid limit}

$250 \mathrm{~g}$ of air-dried lateritic soil sample passing sieve No. $40(0.425 \mathrm{~mm}$ aperture $)$ was placed on the cleaned flat glass plate, and a considerable amount of distilled water was added and mixed thoroughly with a spatula until a uniform paste is formed. A portion of paste was placed on the Casagrande device using spatula depend and a groove was made which divided the soil paste into nearly two equal halves inside the bowl of Casagrande apparatus. The crankshaft of the apparatus was turned to give blows to the soil paste until the two halves nearly closed. The number of blows which closed the groove was recorded. A small portion of the soil in the apparatus was taken for moisture content determination. The water used for mixing was subsequently added such that the number of blows which closes the groove is within the range of $1-10,10-20,20-30,30-40$ and $40-50$ respectively. The graph of moisture content against the number of blows was plotted and the liquid limit was evaluated as moisture content at twenty-five blows. The procedure was repeated for the various cement-CCA stabilized lateritic soil 
samples.

\section{Plastic limit}

$50 \mathrm{~g}$ of the sample passing sieve No. $40(0.425 \mathrm{~mm}$ aperture $)$ was mixed with sufficient water until a paste of good consistency was formed. This was kneaded between the palms of the hands, moulded and rolled until a thread of $3 \mathrm{~mm}$ in diameter was formed in accordance with BS1377 (1990). The soil was kneaded together to form a uniform mass and rolled again. The process of alternative kneading and rolling continued until the thread crumbles and the soil can no longer be rolled into a thread. The pieces of crumbled soil thread were collected for moisture content determination. The same procedure was repeated for various cement-CCA stabilized lateritic soil samples.

The plasticity index was determined as the algebraic difference between the liquid limit and the plastic limit.

\section{Compaction}

West African Standard (WAS) was used for the work since the material is to be used on-site as a subbase material. Air-dried material of 3000 grams was measured with the weighing balance. The first portion of the material will be mixed inside the tray with a mixing hand trowel after adding $5.5 \%$ of water. The uniformly mixed specimen was divided into 5 parts and a scoop was use to fill into the mould. a $4.5 \mathrm{~kg}$ rammer is required, with five layers, each layer receiving 10 blows. After the compaction, the collar was detached from mould and the top was scrapped to level with mould edge then the weight of the mould and the compacted specimen were taken. The bulk density was calculated for each compacted samples: The dry density is plotted against the moisture content and from these maximum dry density and optimum moisture content was determined. The procedure was repeated for the samples mixed with $0-12 \%$ corncob ash in a step concentration of $3 \%$ and simultaneously with $2.5 \%$ and $5 \%$ of cement at a varying percentage of the corncob.

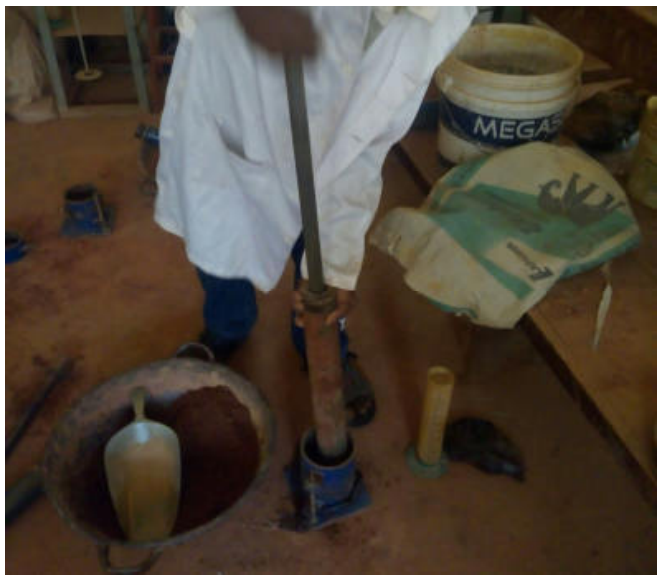

Figure 2: Compaction Apparatus

\section{California bearing ratio (CBR)}

The procedure employed for the compaction test was adopted except the CBR mould was used. 5000g of lateritic soil mixed with a quantity of water determined from $\mathrm{OMC}$ value was compacted in five layers using sixty-three (63) blows of $4.5 \mathrm{~kg}$ rammer dropped from the height of $450 \mathrm{~mm}$ on each layer. Compacted soil specimen with the top face was placed on the lower plate of the CBR loading machine (Figure 2) with surcharge mass on top. $2.5 \mathrm{~kg}$ annular mass is placed on the soil surface to prevent upheaval of soil into the hole of the surcharge mass. Penetration plunger was set to the top of of the specimen to establish full contact between the plunger and the specimen with the load dial gauge and displacement dial gauge on zero. The load was applied on the plunger at the rate of penetration of $1.25 \mathrm{~mm}$ per minute. The load dial gauge readings corresponding to penetration at 0.5 , 1.0, 2.0, 2.5, 3.5, 5.0, 6.5 and 7.0 were recorded. The same procedure was repeated for the bottom of the sample. Thereafter the mould was removed from the machine, extruded and the moisture content of the soil specimen was determined. The same procedure was repeated for the samples admixed with $0-12 \%$ CCA and stabilized with $0-$ $5 \%$ of cement. For the soaked samples, the above procedures were repeated except that the samples were soaked in water for 48 hours prior to testing.

\section{Unconfined Compressive Strength (UCS)}

Soil sample compacted at OMC and cored to $23.5 \mathrm{~mm}$ by $47 \mathrm{~mm}$ in size and wax-cured for 7 days was placed directly on the compression device with hydraulic-actuated loading piston but electronically operated as shown in Figure 3 . A load of $44.5 \mathrm{kN}$ or $222.5 \mathrm{kN}$ capacity was fastened to the piston to measure load on the specimen. The 
test data was displayed on the panel control board readouts.

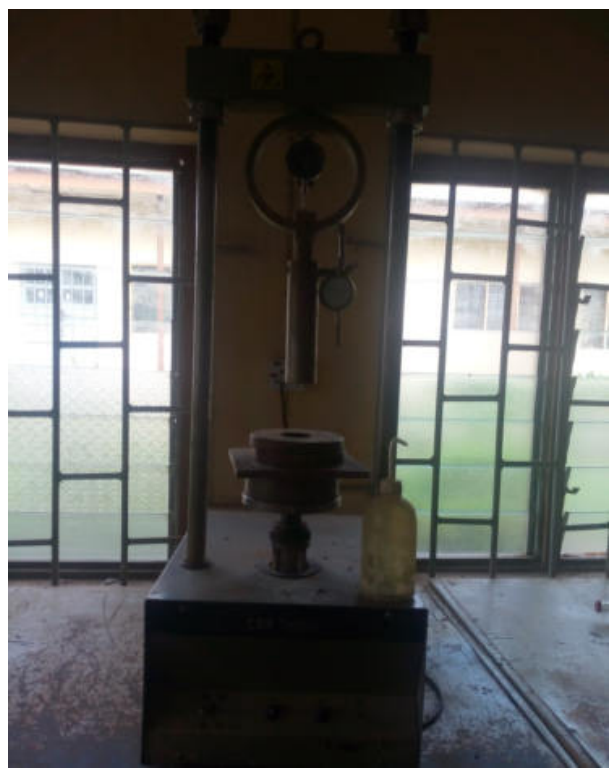

Figure 3: CBR Apparatus

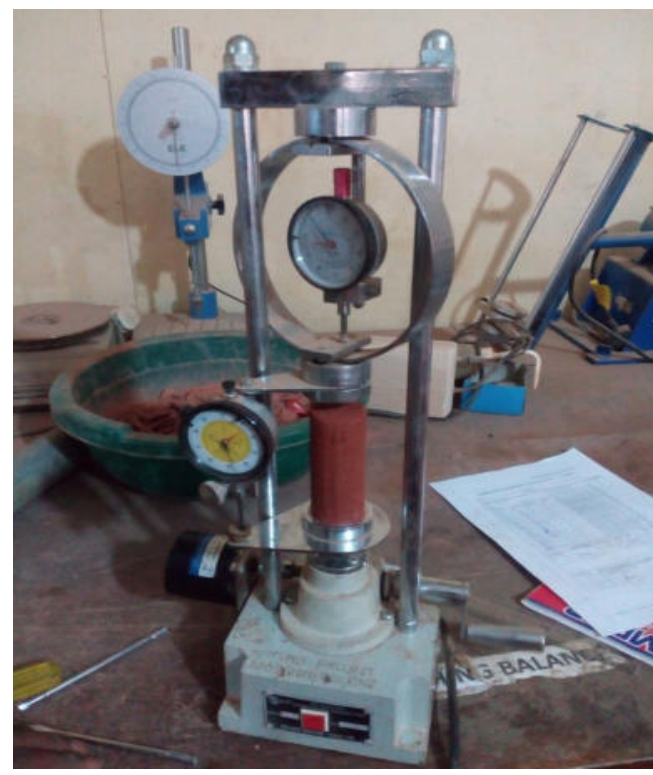

Figure 4: UCS Machine

\section{Results and Discussion}

\subsection{Properties of the natural laterite soil}

The physicomechanical properties of the natural laterite were presented in Table 2. This soil has a natural moisture content of $15.4 \%$ with a specific gravity of 2.43 , percentage passing sieve $75 \mu \mathrm{m}$ (No. 200) of 56.15\% and plasticity index of $15.30 \%$. Since the percentage passing sieve No. 200 is greater than 35\%, and the plasticity index is greater than $12 \%$, the soil is described as poor subgrade material according to Nigerian Highway Specification for Road and Bridges, (1997). The degree of percentage fine in the natural soil makes it have high affinity for water and susceptibility to swelling. The soil is classified as A-7-5 (10) and CL (Low plasticity clayey soil) according to American Association of State Highway and Transportation Officials (AASHTO) (ASSHTO, 1986) and Unified Soil Classification System, USCS (ASTM, 1992).

Table 2. Properties of the natural lateritic soil used

\begin{tabular}{ll}
\hline Properties & Result \\
\hline Natural Moisture Content (\%) & 15.50 \\
Specific gravity & 2.43 \\
Percentage passing sieve $75 \mu \mathrm{m}$ (No. 200) & 56.15 \\
Liquid Limit (\%) & 45.2 \\
Plastic limit (\%) & 28.57 \\
Plasticity Index (\%) & 15.30 \\
AASHTO Classification & A-7-5 (10) \\
USCS Classification & CL \\
OMC at WAS Compaction (\%) & 18.3 \\
UCS at WAS Compaction (Cured) $\left(\mathrm{kN} / \mathrm{m}^{2}\right)$ & 20.17 \\
\hline
\end{tabular}

\subsection{Effect of Corn cob ash-cement admixtures on the particle size distribution of lateritic soil}

Variations of the particle size distribution of lateritic soil treated with up to $12 \%$ of CCA and $5 \%$ cement are presented in Figure $4 \mathrm{a}$ - c. The percentage passing sieve No. 200 decreased with increasing content of CCA up to $9 \%$ for 0 to $5 \%$ cement and then increased. The decrease in the percentage fine content up to $9 \%$ results from the flocculation and agglomeration of soil-CCA mixture coupled with pozzolanic reaction between cement and CCA which both produce hydrated calcium silicates (CHS) and hydrated calcium aluminates (CHA) which act as binder for the fine particles within the soil and hence reduction in the fine content as the percentage CCA increases. 


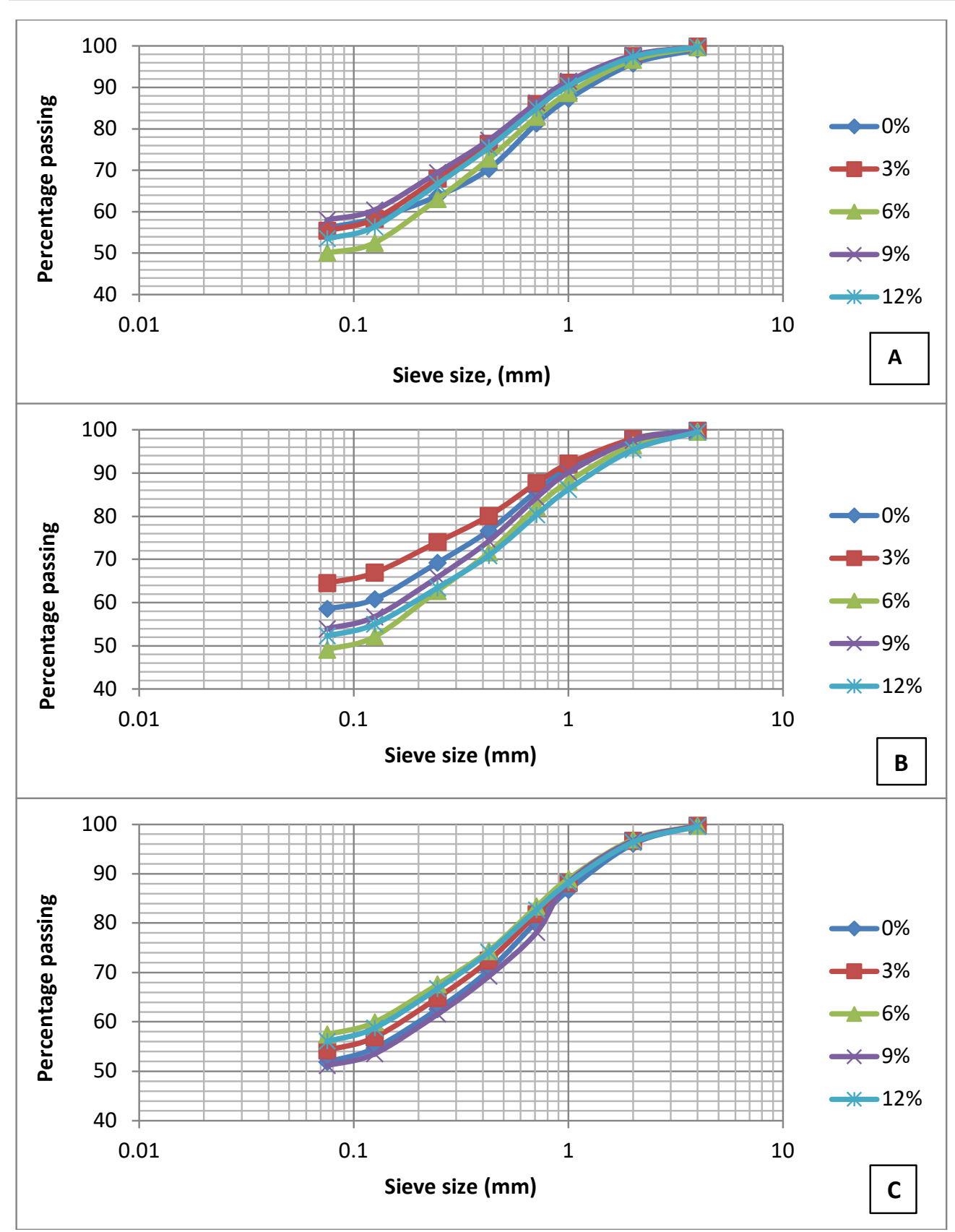

Figure 4: Variation of particle size distribution with corncob ash (CCA) for (A) $0 \%$, (B) $2.5 \%$ and (C) $5 \%$ cement stabilized lateritic soil

\subsection{Effect of Corn cob ash and Cement as admixture on the consistency limits}

Variations of the liquid limit, plastic limit and plasticity index of the soil with percentages of CCA for each of the three cement stabilized samples are presented in Figure $5 \mathrm{a}-\mathrm{c}$. The liquid limit of the soil decreased with increasing CCA content but increased with cement content up to $2.5 \%$ cement and thereafter increased due to the hygroscopic nature of residual cement within the mixture. The liquid limit ranged from $45.2 \%$ at $0 \% \mathrm{CCA}$ and $0 \%$ cement to $43 \%$ at $12 \%$ CCA and 5\% cement. However, the plastic limit increased with increasing content of both CCA and cement. This is expected since the formation of cementitious materials, $\mathrm{CSH}$ and $\mathrm{CAH}$, from the pozzolanic and flocculation reactions of CCA and cement with soil, renders the soil to be more plastic. The plastic ranged from $25.03 \%$ at $0 \%$ CCA and $0 \%$ cement to $43.86 \%$ at $12 \%$ CCA and $5 \%$ cement. The plasticity index, which is a measure of the plasticity of the soil, decreased with increasing CCA and cement contents for each of the $0 \%, 2.5 \%$ and $5 \%$ cement. After the addition of $12 \%$ CCA to the soil, its plasticity reduced by 52,47 and $46 \%$, for $0,2.5$ and 
$5 \%$ cement addition, respectively.

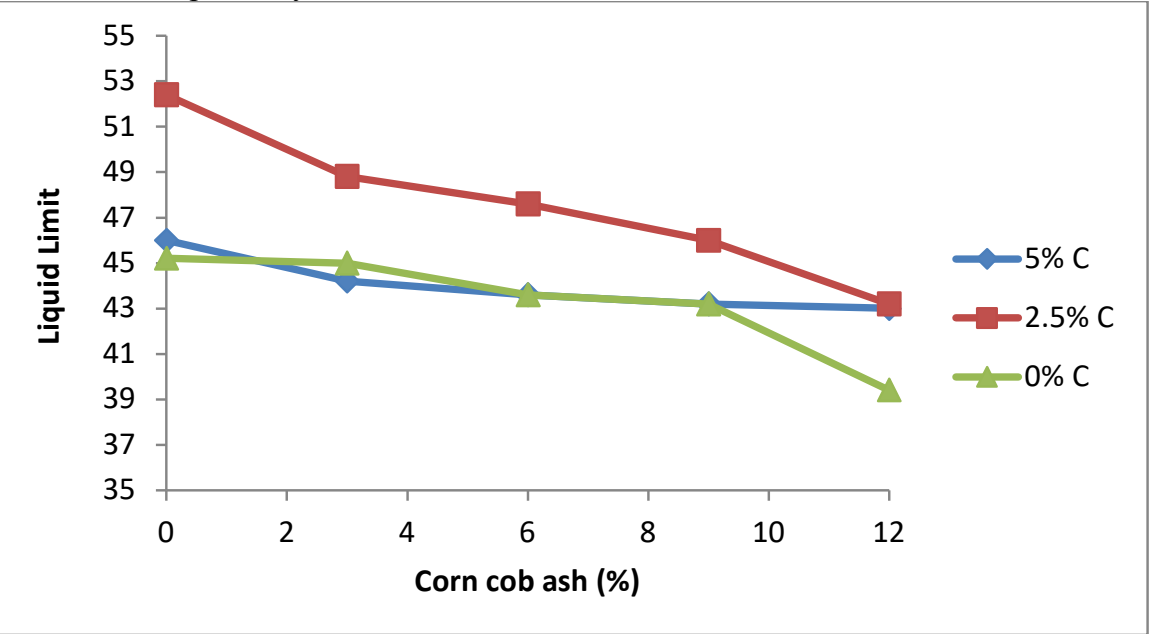

Figure 5a Variation of liquid limit with CCA content for lateritic stabilized with cement

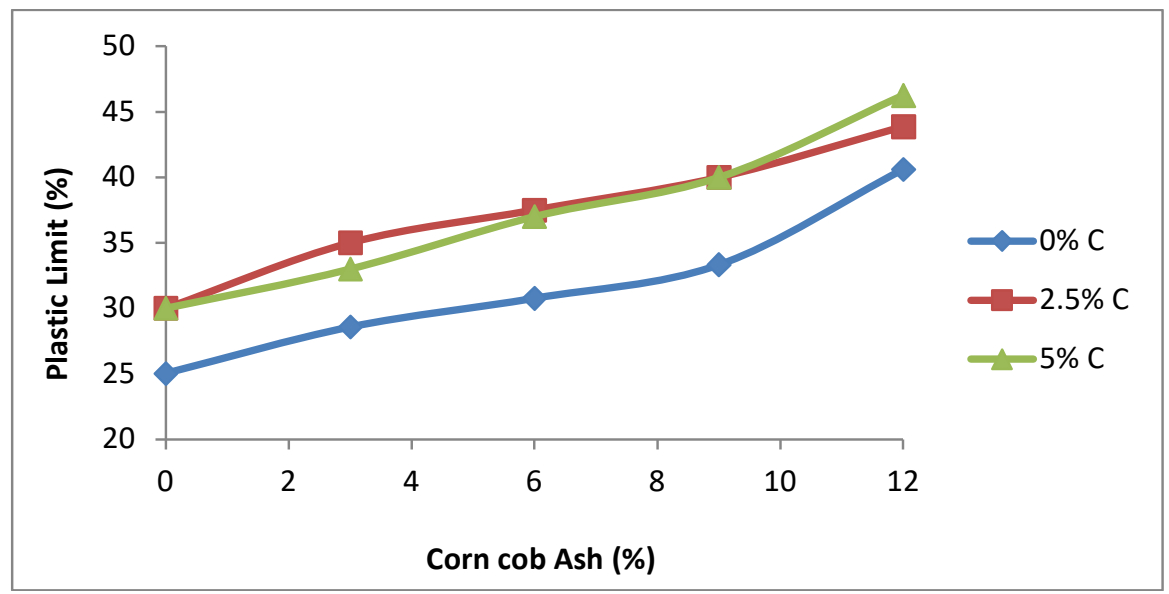

Figure 5b Variation of plastic limits with CCA content for lateritic stabilized with cement

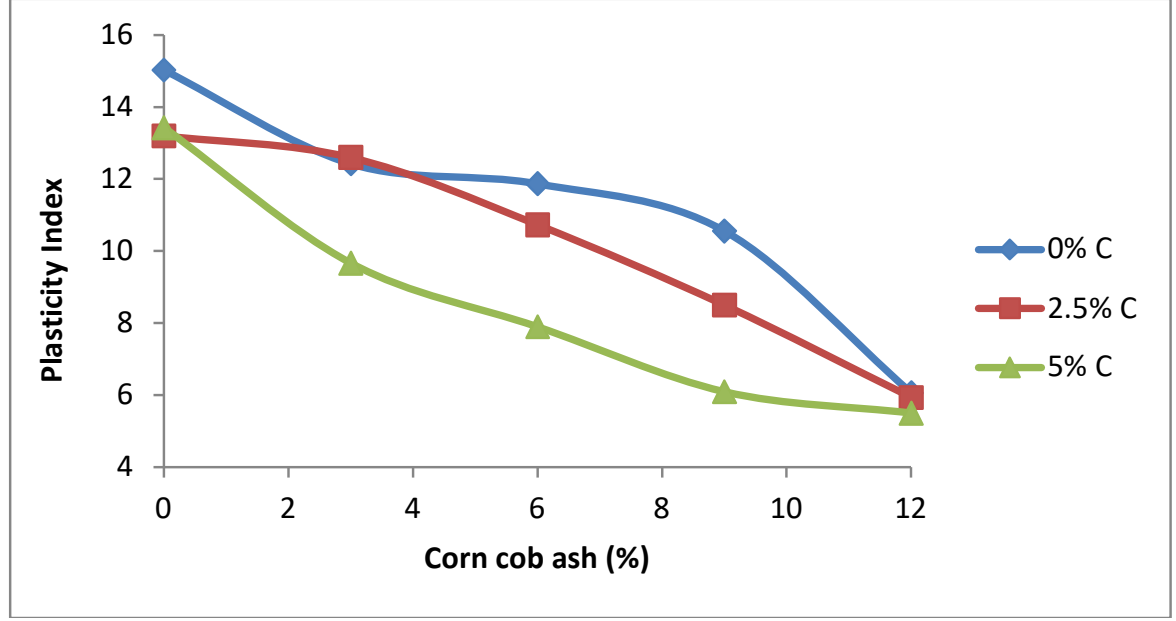

Figure 5c Variation of plasticity index with CCA content for lateritic stabilized with cement

Dissociation between the lime-producing cement and water in the stabilized soil (Equation 1) with subsequent cation exchange of $\mathrm{Ca}^{2+}$ with the clay particles of the soil after the addition of varying percentages of the CCA (Equation 2), which reduced the moisture-holding capacity of the soil, and consequently minimizing the interaction between the water and clay-size particles is responsible for the reduction in plasticity index and enhancement of 
workability of the soil (Akinwumi et al., 2015; Amadi, 2010).

$$
\begin{array}{ll}
\mathrm{CaO}+\mathrm{H}_{2} \mathrm{O} \rightarrow \mathrm{Ca}(\mathrm{OH})_{2} & \text { (Dissociation) } \\
\mathrm{Ca}(\mathrm{OH})_{2} \rightarrow \mathrm{Ca}^{2+}+2(\mathrm{OH})^{-} & \text {(Cation exchange) }
\end{array}
$$

Based on the Atterberg limits and particle size distribution of the CCA-Cement stabilized samples, the classifications of the samples based on AASHTO classification ranged between A-7-5 to A-7-6 as CCA content increased for all 0, 2.5 and 5.0\% Cement stabilized soil. Since all the results were A-7-5 and above, it indicates that the soil contains a high percentage of silt and clay hence the soil is not a good material for highway construction.

\subsection{Effect of corn cob ash and cement as admixture on the compaction characteristics}

The variations of maximum dry densities and optimum moisture content, as compaction characteristics, with CCA in the soil sample were graphically shown in Figures $6 a$ and $6 \mathrm{~b}$ respectively. Maximum Dry Density (MDD) of the soil generally increased with the increasing contents of CCA and cement in the soil. Peak MDD was obtained at $12 \%$ and $5 \%$ of CCA and cement contents, respectively. Similarly, the Optimum Moisture Content (OMC) increased up to $9 \%$ CCA and later decreased for each of the 0, 2.5 and 5\% cement stabilized soils. Although the specific gravity of CCA is low within the mixture, the density of the soil-CCA-cement mixture was enhanced by the presence of cement of higher specific gravity. Also, the flocculation and agglomeration of soil-CCA, pozzolanic reaction between soil, CCA and the lime generated from the hydration of cement, as well as the cementation of the soil particles by the hydrated cement produced a more dense mixture though at higher moisture content. Similar results were reported (Akinwumi and Aidomojie 2015; Oluremi et al., 2016a; Oluremi et al., 2016b).

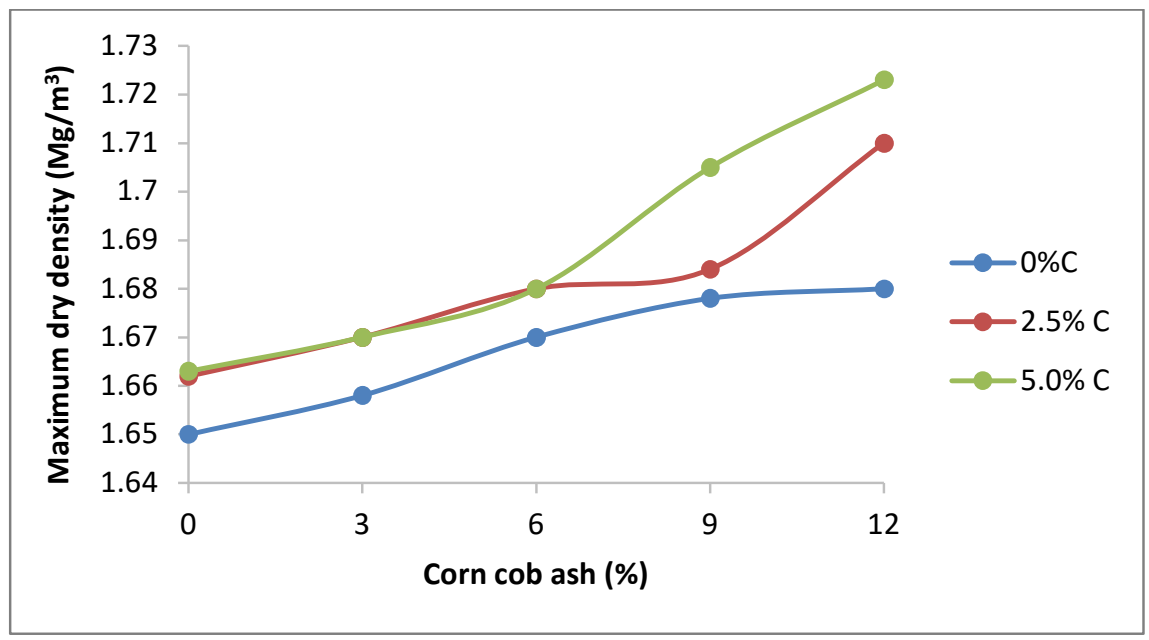

Figure 6a. Variation of maximum dry density with corn cob ash for $0-5 \%$ cement stabilized lateritic soil.

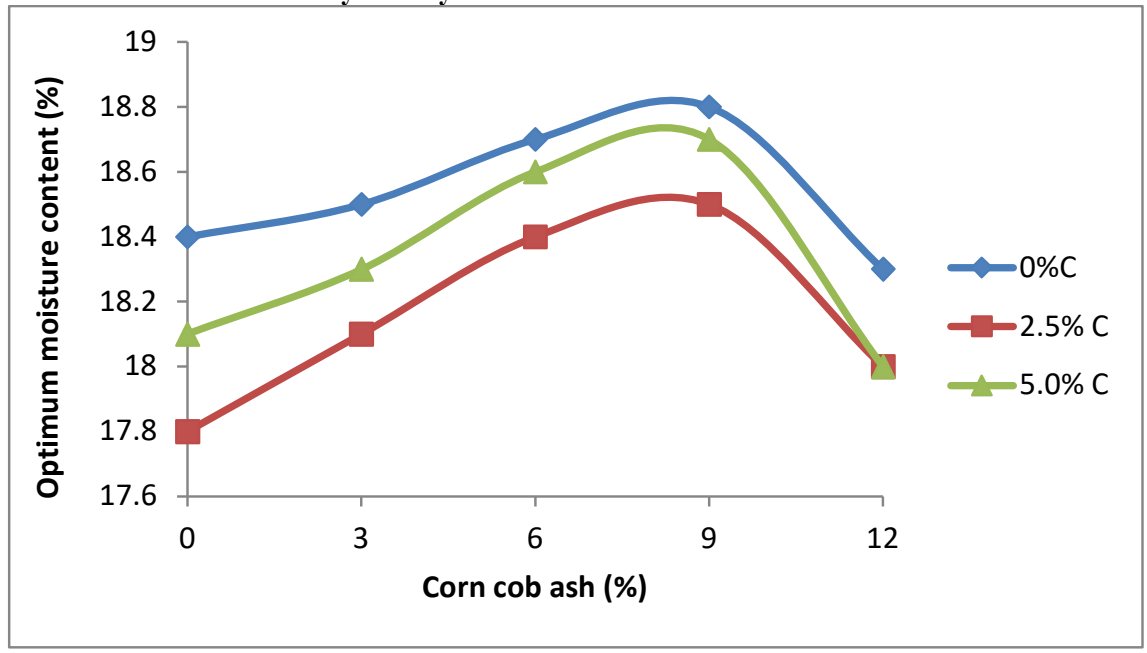

Figure 6b. Variation of Optimum moisture contents with corn cob ash for $0-5 \%$ cement stabilized lateritic soil 


\subsection{Unconfined Compressive Strength (UCS)}

The variation of the unconfined compressive strength (UCS) with varying percentages of corncob ash on $0,2.5$, and 5\% cement stabilized lateritic soil sample are presented graphically in Figure 7. UCS increased with increasing content of both CCA and cement. The values of UCS increased from 20.71 to $152.44 \mathrm{kN} / \mathrm{m}^{2}, 34.52$ to 186.72 $\mathrm{kN} / \mathrm{m}^{2}$ and 60.44 to $372.84 \mathrm{kN} / \mathrm{m}^{2}$ for $0,2.5$ and $5 \%$ cement content, respectively.

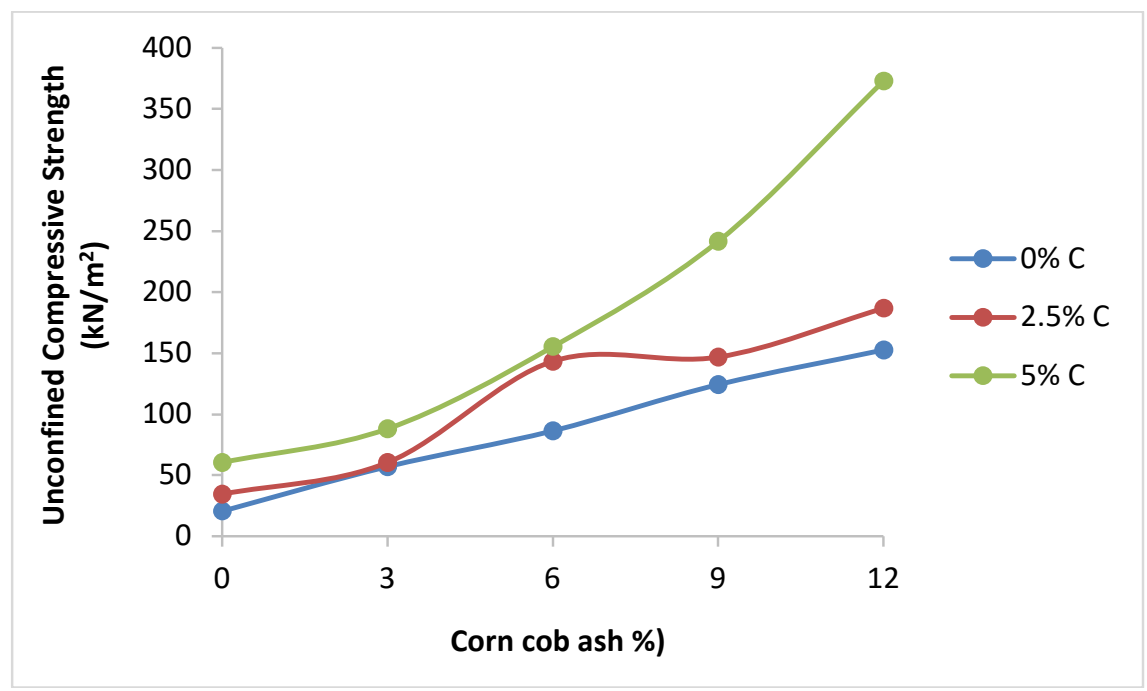

Figure 7. Variation of unconfined compressive strength with corncob ash content

The increase in the UCS of the samples is due to the presence of cementitious material, CSH and CAH formed from the pozzolanic reaction of CCA and soil siliceous materials with lime liberated from hydrated cement, within the soil matrix and the cementation of the soil particles by the hydrated cement. This gave a strong interparticle bonding for the soil matrix and hence higher strength as contents of the admixtures increases. Similar results were reported in (Mamlouk and Zaniewski, 2006).

\subsection{California Bearing Ratio (CBR)}

The graphical representation of the variation of California Bearing Ratio (CBR) with the varying percentages of corncob ash on $0,2.5$, and $5 \%$ cement stabilized lateritic soil samples, after 6 days curing and 24hours soaking conditions, are presented Figure 8.

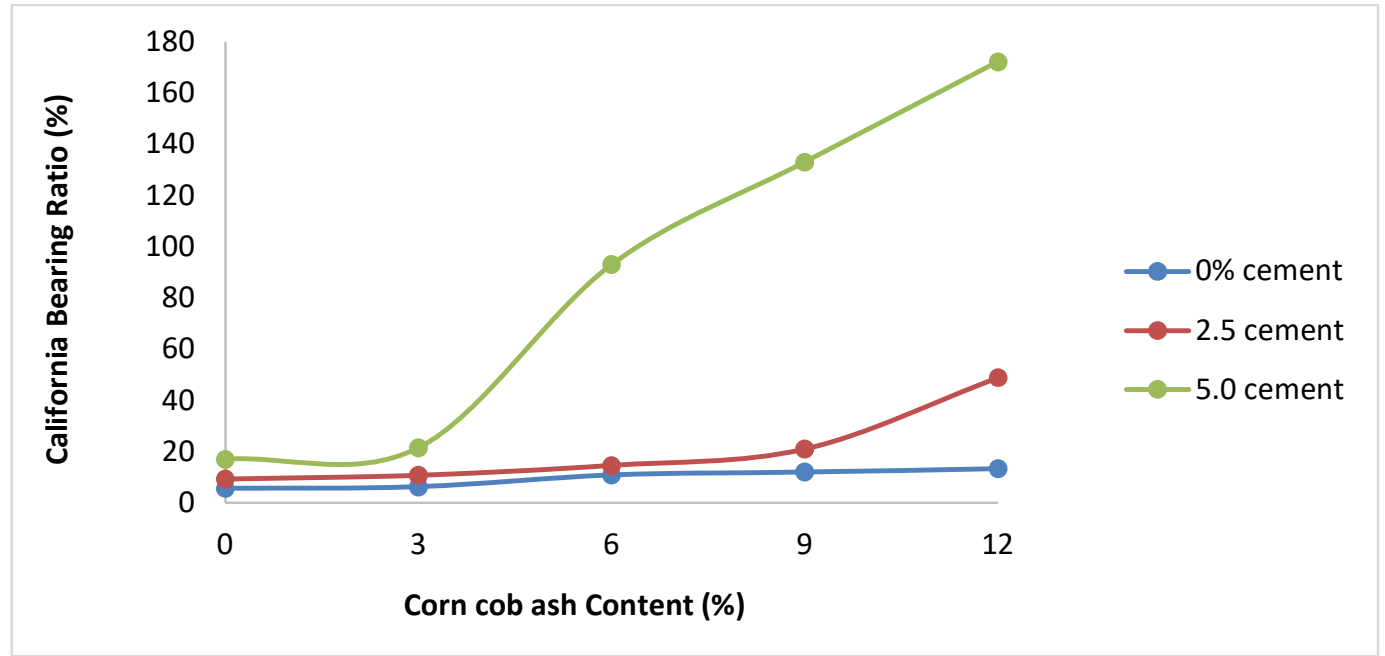

Figure 8. Variation of California bearing ratio with corncob ash content 
The CBR values of the natural soil ranged from 5.68 to $12.05 \%$ at $12 \%$ CCA. According to Gidigasu and Dogbey (1980), a minimum CBR value between $60-80 \%$ and $20-30 \%$ is required of any material for base and subbase course, respectively in flexible pavement when compacted at optimum moisture content and 100\% West African standard. Also, The Nigerian General Specification for Roads and Bridges by The Federal Ministry of Highway and Transportation (1997), stipulated a soaked CBR value of not less than $30 \%$ for subbase material, the natural soil could be used as subgrade material only.

For each of the 2.5 and $5.0 \%$ cement stabilized lateritic soil, the soaked CBR value increased from 9.36 to $42.85 \%$ and 17.04 to 133.04 , respectively, with increasing content of CCA. Consequently, the stabilized soil became more suitable for flexible pavement application. Based on these results, this lateritic soil stabilized with $2.5 \%$ cement and admixed with $12 \%$ CCA could be used as subbase material. Similarly, since this soil stabilized with $5 \%$ cement admixed with up to $12 \%$ CCA content gave a soaked CBR value greater than the $80 \%$ required by The Federal Ministry of Highway and Transportation (1997), then, it could be used as a base material once the plasticity index of this stabilized soil is not less than the required 12\%. This result is similar to Joel and Agbede (2011) which studied the stabilization of a lateritic soil (A-2-7) with cement and sand mixtures; the cured and soaked CBR of the stabilized soils increased with increasing stabilizer contents.

\section{Conclusion}

From this study, the following conclusions were deduced:

1. The stabilization of the lateritic soil, classified as A-7-5 (10) and CL based on AASHTO and USCS classification systems, with up to 5\% cement and 12\% CCA does not significantly enhance its plasticity and particle size distribution since the classification of the soil was still within A-7-5 and A-7-6. Therefore corn cob ash (CCA) cannot be used as a stand-alone stabilizer for this lateritic soil. Also, a more potent stabilizer for clay soil such as lime would be needed.

2. Addition of CCA to this cement stabilized lateritic soil reduced the liquid limit and increased the plastic limit with the corresponding reduction in the plasticity index of the clay soil which as a result improved its consistency and workability.

3. Both the Maximum Dry Density (MDD) and Optimum Moisture Content (OMC) of the stabilized soil sample increased with the increasing content of CCA and cement except for $12 \%$ CCA where the OMC dropped.

4. The Unconfined Compressive Strength (UCS) and California Bearing Ratio (CBR) of the soil increased with the increasing percentage of cement and CCA.

Based on the results of this study, it is therefore recommended that the mixture of $12 \% \mathrm{CCA}$ and $2.5 \%$ cement could be used as to stabilized A-7-5 (10) lateritic soil for use as subbase material and 12\% CCA and 5.0\% cement could be used as to stabilized A-7-5 (10) lateritic soil for use as base material for improving pavement structure in terms of strength, stability and workability.

\section{REFERENCES}

AASHTO (1986). Standard for transportation materials and methods of sampling and testing, fourteenth edition. AASHTO: Washington, DC.

Adesanya, D. A., and Raheem, A. A. (2009). A study of the workability and compressive strength characteristics of corn cob ash blended cement concrete. Construction and Building Materials, 23, 311-317.

Akinrinlola O.A. (1991) Some geotechnical, chemical and mineralogical properties of residual lateritic soils occurring in Ilorin, Kwara State, Nigeria. Unpublished M.Sc. thesis, University of Ilorin. 122p.

Akinwumi, I. I. and Aidomojie, O. I. (2015) Effect of corncob ash on the geotechnical properties of lateritic soil stabilized with Portland cement. International Journal of Geomatics and Geosciences, 5 (3): 375-392. ISSN $0976-4380$

Amadi A. (2010). Evaluation of Changes in Index Properties of Lateritic Soil Stabilized with Fly Ash. Leonardo Electronic Journal of Practices and Technologies, 17, 69-78.

ASTM (1992). Annual book of ASTM standards. American society for testing and materials, ASTM International: West Conshohocken, PA.

Berthelot, C., Raducanu, C., Scullion, T., and Luhr, D. (2005). "Investigation of Cement Modification of Granular Base and Subbase Materials using Triaxial Frequency Sweep Characterization". Proceedings of the 84th Annual Meeting of the Transportation Research Board. 9-13 January 2005. Transportation Research Board: Washington, D.C. Paper 05-1371. 
British Standard Institution (1990). Methods of Test for Soils for Civil Engineering Properties (BS 1377). British Standard Institution: London, UK. 143p.

British Standard Institution (1990). Methods of Test for Stabilized Soils for Civil Engineering Properties (BS 1924). British Standard Institution: London, UK. 143p.

Brooks, R. M. 2009. Soil Stabilization with Fly Ash and Rice Husk Ash. International Journal of Research and Reviews in Applied Sciences, 1 (3): 209-217.

Chungsangunsit, T., Gheewla, H., and Patumsawad, S., (2009). Emission Assessment of Rice Husk combustion for power production, Engineering and Technology Journal. 53: 1070 - 1075

Federal Ministry of Highway and Transportation (1997) Nigerian Highway Specification for Road and Bridges, (Revised Edition), Abuja, Nigeria.

Gadzama, E.W. (2009). Evaluation of Soil Samples From Federal University of Technology, Yola Site. Nigerian Journal Of Engineering. 15(2): 80-88.

Gidigasu, M. D., and Dogbey, J. L. K. (1980). Geotechnical characterization of lateritized decomposed rocks for pavement construction in dry sub-humid environment. 6th Southwest Asian conference on soil engineering, 1, 493-506, Taipei.

Jimoh, Y. A., and Apampa, O. A. (2014). An evaluation of the influence of corn cob ash on the strength parameters of lateritic soils. Civil and Environmental Research, 6(5), 1-10.

Mamlouk, M. S., and Zaniewski, J. P. (2006). Materials for Civil and Construction Engineers, second edition, $5(4), 6-13$

Muhunthan, B and Sariosseiri, F (2008). 'Interpretation of Geotechnical Properties of Cement Treated Soils' Washington State Transportation Centre (TRAC). WA-RD 715.1

Nehdi, M., Duquette, J., and El-Damatty, A. (2003). Performance of rice husk ash produced using a new technology as a mineral admixture in concrete. Cement and Concrete Research, 33, 1203-1210.

O'Flaherty, C.A (2002). Highways: The location, design and maintenance of road pavements. 4th ed. Butterworth Heinemenn, Jordan Hill Oxford.

Ola, S.A. 1975. Stabilization of Nigerian Laterite Soils with Cement, Bitumen and Lime. Proceedings of the sixth Regional conference for Africa on Soil Mechanics and Foundation Engineering. Durban, South Africa. $1: 145-152$.

Ola, S.A. 1983. Geotechnical Properties and Behaviour of Some Nigerian Lateritic Soils. In: S.A. Ola. Tropical Soils of Nigeria in Engineering Practice. A.A. Balkema: Rotterdam, The Netherlands. 61-84.

Oluremi, J. R, Yohanna, P., Ishola, K, Yisa, G. L, Eberemu, A. O., Ijimdiya, S. T. and Osinubi, K. J. (2017) Plasticity of Lateritic Soil Admixed with Selected Admixtures accepted for publication in Environmental Geotechnics, Institute of Civil Engineering (ICE), United Kingdom. http://dx.doi.org/10.1680/jenge.15.00085

Oluremi, J. R., Osuolale, O. M., Adeoye, T. T. and Akingbade, A. A. (2016b) Strength Development in Lateritic Soil Stabilised with Coconut Shell Ash for Highway Pavement Construction, Innovative Systems Design and Engineering, 7 (11): 49-56.

Oluremi, J. R., Siddique, R. and Adeboje, E. P. (2016a) Stabilization Potential of Cement Kiln Dust Treated Lateritic Soil. International Journal of Engineering Research in Africa. 23: 52-63 doi:10.4028/www.scientific.net/JERA.23.52

Oluremi, J.R. Adedokun, S. I. and Osuolale, O. M. (2012) Stabilization of Poor Lateritic Soils with Coconut Husk Ash, International Journal of Engineering Research \& Technology (IJERT) 1 (8): 1-9, www.ijert.org

Osinubi, K. J. (2000). Stabilization of tropical black clay with cement and pulverised coal bottom ash admixture. In: Advances in Unsaturated Geotechnics. Edited by Charles, D., Shackelford, Sandra L. Houston and NienYin Cheng. ASCE Geotechnical Special Publication, 99: 289-302.

Osinubi, K. J. (2006). Influence of compactive efforts on lime-slag treated tropical black clay Journal of Materials in Civil Engineering, ASCE. 18 (2): 175-181

Osinubi, K. J. and Medubi, A. B. (1997) Effect of lime and phosphatic waste admixture on tropical black clay. Proceedings, 4th Regional Conference on Geochemical Engineering, GEOTROPIKA '97, Johor Bahru, 1112 Nov., Malaysia, pp. 257-272.

Osinubi, K. J., Akinmade, O. B. And Eberemu, A. O. (2009). Stabilization potential of locust bean waste ash on black cotton soil. Journal of Engineering Research, University of Lagos, 14 (2): 1-13.

Osinubi, K. J., Oluremi, J. R., Eberemu, A. O., and Ijimdiya, S. T. (2017) Chemical Interaction compatibility of Lateritic Soil stabilized with Wood waste ash with municipal solid waste leachate. Wastes and Resources Management, 170 (WR3+4): 128-138. Institute of Civil Engineering (ICE) http://doi.org/10.1680/jwarm.17.00012

Osinubi, K. J., Oyelakin, M. A. and Eberemu, A. O. (2011). Improvement of black cotton soil with ordinary 
Portland cement - locust bean waste ash blend. The Electronic Journal of Geotechnical Engineering, Vol. 16, Bund. F, pp. 785-796.

Osinubi, K.J. 1998. Influence of Compaction Delay on the Properties of Cement-Stabilized Lateritic Soil. Journal of Engineering Research. 6 (1):13-26.

Osinubi, K.J. and Nwaiwu, C.M.O. 2006. Compaction Delay Effects on Properties of Lime Treated Soil. Journal of Materials in Civil Engineering. 18(2):250-258.

Osipov V. I. and Filimonov, S. D., (2002). Strengthening and reinforcement of weak soils by the 'geocomposite' method, Osn., Fundamental. Mekh. Gruntov, 5, 15-21.

Osula, D.O.A. 1989. "Valuation of Admixture Stabilization for Problem Laterite. Journal of Transportation Engineering. 115(6):674-687.

Osuolale, O. M., Oseni, A. A. and Sanni, I. A. 2012. "Investigation Of Highway Pavement Failure Along Ibadan - Iseyin Road, Oyo State, Nigeria” International Journal of Engineering Research \& Technology (IJERT) 1(8): $1-7$

Scullion, T. and Harris, P. 1998. Forensic Evaluation of Three Failed Cement Treated Base Pavements. Transportation Research Record. 1611:10-18.

Udoeyo, F. F. (2002). Sawdust ash as concrete materials. Journal of Materials in Civil Engineering, 14(2), 173176.

Zhang, C., Geng, Z., Cai, M., Zhang, J., Liu, X., Xin, H., and Ma, J. (2013). Microstructure regulation of super activated carbon from biomass source corncob with enhanced hydrogen uptake. International Journal of Hydrogen Energy, 38, 9243-9250.

Zhang, M., Wang, F., Su, R., Qi, W., and He, Z. (2010). Ethanol production from high dry matter corncob using fed-batch simultaneous saccharification and fermentation after combined pretreatment. Bioresource Technology, 101, 4959-4964. 